CRÍTICA, Revista Hispanoamericana de Filosofia

Vol. XXV, No. 74 (agosto 1993): 23-63

\title{
PASCAL AND THE PROBLEM OF A COMMON WORLD
}

\author{
JENNIFER YHAP \\ Concordia University
}

In contemporary philosophy, much has been made of the problem of a common world. This preoccupation no doubt stems from the inherent nature of the difficulty itself, for the problem of a common world is not one but many. In its simplest form, we can reduce it to the following two questions: what is it that is real of a common world; and what is it that is true of a common world? Our intention is to remain within the purview of the latter question. In turn, the question concerning the truth of a common world admits of two sides, that of the object and that of the subject. We elect to consider the question only as it relates to the subject. Hence the problem may be restated in the following terms: amongst a number of subjects, what is the intelligible element which enables the subjects to speak truly of a world as known to themselves each and severally. And while the problem occupies much current thought, a brief historical regard betrays the constant concern of philosophers of all ages in respect of this problematic. Each philosopher conceives the world according to the requisites of his science. With the Pensées of Pascal, we discern the beginnings of an unique response to the question: it is the notion of instinct grasped as cognitive condition. ${ }^{1}$

1 Blaise Pascal, Pensées, trans. A.J. Krailsheimer (London: Pen- 
We suggest that the notion of instinct is the intelligible element situated within the subject which grounds our understanding of the world as intersubjectively accessible. It is a structure of understanding which is at once shared and scientific.

\section{Context}

For the English speaking philosopher, this problem has been variously conceived either upon pragmatic grounds or upon linguistic grounds. Their approach to the problematic is well attested to in the literature of the respective schools of thought. In the case of a pragmatist such as William James, the problem is to be addressed in terms of mental states and acts of transition:

But now what do we mean by pointing, in such a case as this? What is the pointing known-as, here? To this question I shall have to give a very prosaic answer - one that traverses the prepossessions not only of common sense and scholasticism, but also those of nearly all the epistemological writers whom I have ever read. The answer, made brief, is this: The pointing of our thought to the tigers is known simply and solely as a procession of mental associates and motor consequences that follow on the thought, and that would lead harmoniously, if followed out, into some ideal or real context, or even into the immediate presence, of the tigers (“The Tigers In India", pp. 44-45).

The individual's personal psychological state issues forth into a real result: an harmoniously ordered context of "mental associates and motor consequences", that is to say, of thought and action. This, then, is the objective content of pointing. We draw attention to the following considerations. First, the intelligible element which enables the

guin Books, 1966). In the Pensées of Pascal, all references to the English text are made consistent with the numeration of this edition. 
subject each and severally to affirm a common world is the notion of procession. It is neither the particular mental state nor the particular motor consequence which grounds the shared relation of the world. Rather, emphasis is placed on the notion of procession; that is, the continuous unfolding of a series of mental states and motor consequences which may or may not issue forth into coalescence. The origin of this procession is left ignored. Second, the notion of harmony is conspicuous. This notion does not of itself identify the real or ideal nature of the objective content of the intelligible element. Rather, that which it explains is the noetic standard necessary for the true understanding of an objective content - in this case, our knowledge of tigers. Hence the notion of harmony is important to the elucidation of the problem of a common world to the extent that it serves as the criterion for the determination of truth within the psychic procession. This criterion is understood to apply to the subject each and severally. Elsewhere, James clarifies the result of this mental procession: "In such a world transitions and arrivals (or terminations) are the only events that happen, tho they happen by so many sorts of path. The only function that one experience can perform is to lead into another experience; and the only fulfilment we can speak of is the reaching of a certain experienced end. When one experience leads to (or can lead to) the same end as another, they agree in function" ("The Relation Between Knower And Known", pp. 111-112). The notion of function constitutes the third element of noesis within the pragmatic philosophy. It serves to distinguish the causal relations and terms of reference within the psychic procession of the subject. These three notions of procession, harmony, and function will be situated within the Pensées of Pascal. More especially, we shall maintain the position that the notion of instinct as cognitive condition of the 
subject includes each of these elements of noesis in a way that is particular to Pascal.

Conversely, for the philosopher of language, the problem of a common world is to be understood in terms of linguistic analysis. A clear and concise exposition of this view may be had in the work by A.J. Ayer entitled The Problem of Knowledge. He states:

The answer is that there is a reason only if one chooses to find one. The question whether an object is public or private is fundamentally a question of language; it depends upon the conventions which we follow in making judgements of identity. Thus physical objects are public because it makes sense to say of different people that they are perceiving the same physical object; mental images are private because it does not make sense to say of different people that they are having the same mental image; they can be imagining the same thing, but it is impossible that their respective mental images should be literally the same (p. 200).

Thus for the philosopher of language, whether something is deemed public or private largely depends upon what we need to be able to say about it. Rather than the felicitous outcome of an harmonious agreement, the conventions of the linguist are founded upon considerations of bare necessity. The public object is public to the extent that we need to be able to speak of it as in public, that is, amongst ourselves. Hence we can speak of the park bench as public because of our need - each and severally - to be able to sit down and enjoy the comfort of the said bench. Our objects are private, on the other hand, insofar as we do not judge it necessary to affirm their presence to ourselves in public; that is, as belonging at once to each and several subjects. Underlying the linguistic approach to the problem appears to be the notion of belonging - of possession: what are those objects which can be said to belong to us each, and what are those objects which can be said to belong to us 
severally. Did Pascal adhere to either of these solutions? We think not. While the texts of Pascal admit of much discussion of a practical and linguistic concern, it would seem to be the case that the solution to the problem of a common world lies elsewhere in the thought of Pascal. The particular reasons for his election of an alternate solution will be provided with the introduction of the notion of method.

Contemporary with Pascal and hence of especial importance to the conception of the problematic is the return of a philosophy of sensualism. It explains our knowledge of the world based upon the postulation of sensible qualities as such qualities clarify the objective content of conception. This approach has its origins in the philosophy of Descartes $^{2}$ and entails the following: there are two kinds of sensible qualities, primary and secondary. The primary qualities are qualities such as size and shape which are fully susceptible of mathematical measurement. As such, they are deemed to be objective in nature. Their presence serves to explain the world as it is commonly known. Conversely, the secondary qualities are qualities such as colour and smell which are not fully susceptible of mathematical measurement. As such, they are deemed to be subjective in nature. Their presence alternately serves to explain the world as it is privately known. Hence there arises the problem of a common world: how, upon the basis of privately known experience, may we accede to have knowledge of a common world? For a person's experience is constituted entirely of secondary qualities which may or may not instruct us upon the nature of primary qualities. The Cartesian so-

2 The influence of Montaigne and of his philosophy of sensualism is manifest in the thought of Pascal. See for example 'Entretien avec M. de Saci sur Epictéte et Montaigne', and fragments Nos. 63-65 in the Brunschvicg edition. However it is not to our present purpose to study the moral and political philosophy of Pascal. 
lution to the problem is to argue for a parallelism between the primary and the secondary qualities. In turn, the truth of this parallelism is founded upon a further consideration: the concept of matter as extension. In the philosophy of Descartes, the concept of matter like the concept of God is innate. As such, it is one of a few universal principles which governs reality, which holds its truth upon grounds of strictly internal validation, and which necessitates the immediate assent of the subject. Hence the Cartesian response is clear: it is the intellectual concept of matter which exists within the intelligible element of the subject, each and severally, which serves to ground a common knowledge of the world. Based upon the certain truth of the innate idea, we are able to elaborate a true knowledge of the world consequent to the analysis of images - secondary qualities - into their conceptual matter. This is the Physics of Descartes.

\section{Instinct and Disposition}

The Pensées of Pascal would appear to offer an interesting solution to the problem of a common world. This solution is the Pascalian notion of instinct: it is the intelligible element which serves to explain the true experience of a world as belonging to a multiplicity of subjects each and severally. Rather than proceed to a study of the problem of a common world based upon the analysis of sensible qualities, Pascal prefers to concentrate his thought upon a form of understanding termed 'instinct'. The solution of Pascal is the introduction of dispositionality as fundamental to the operations of the mind. What then is a disposition? It is the practical application of thought to the sensible reality. We can call it a generic unity of conception which serves to specify the concept. Pascal states: 
What are our natural principles but habitual principles? In children it is the principles received from the habits of their fathers, like hunting in the case of animals. A change of habit will produce different natural principles, as can be seen from experience, and if there are some principles which habit cannot eradicate, there are others both habitual and unnatural which neither nature nor a new habit can eradicate. It all depends on one's disposition (p. 125). ${ }^{3}$

The term 'disposition' is fundamental to the present clarification of the intelligible element of the subject. It enables the specification of the objective content of the idea through a directedness of act of conception toward things of the world. We locate this directedness within instinct.

This notion of instinct must be carefully distinguished from the Cartesian concept of the innate idea. The rest of this section is, therefore, devoted to an elucidation of the major differences between the notion of instinct in Pascal and the innate idea of matter in Descartes. To begin, we suggest that the notion of instinct founds the true knowledge of a common world insofar as it is a natural disposition of the mind to form certain shared concepts under certain shared conditions. The text of Pascal is revealing: it is clearly stated that the principles of the understanding are natural. As well, the examples illustrate the application of these principles to both the rational and the sensible realm of living beings. As a disposition-

3 “Qu'est-ce que nos principes naturels, sinon nos principes accoutumes? Et dans les enfants, ceux qu'ils ont reçus de la coutume de leurs pères, comme la chasse dans les animaux?"

"Une différente coutume nous donnera d'autres principes naturels, cela se voit par expérience; et s'il y en a d'ineffaçable à la coutume, il y en a aussi de la coutume contre la nature, ineffaçables à la nature, et a une seconde coutume. Cela dépend de la disposition" (p. 92). References to the French text of the Pensées are made in accordance with the Brunschvicg edition. Blaise Pascal, Pensées et opuscules. Ed. Léon Brunschvicg (Paris: Librairie Hachette, 1945). 
al form of understanding subsistent within the living being, instinct is a generic reality which directs the application of thought to things. This is unlike the Cartesian innatism which models knowledge of things upon the sensual perception. For Descartes, true knowledge of self and of things may be ascertained consequent to the obviousness of apprehension (Meditations, p 57). Thus we are able to set a first difference between the thought of Pascal and the philosophy of Descartes: for Pascal, the notion of instinct is veridical insofar as it leads to the formation of the first truths of the physical sciences. For Descartes, on the other hand, the innate idea of matter does not lead to the formation of the first principles of the physical sciences; its role is not formative but rather validational in nature.

However, the choice of Pascal away from a philosophy of sensualism does not entail an indifference to the sensible reality. As a practicing scientist, Pascal was fully aware of the importance of the natural sciences. His is not a philosophy which consciously ignores the physical world. Quite the opposite. But unlike his famous contemporary, Pascal did not allow considerations proper to the natural sciences to intrude upon his philosophy, nor conversely did he allow his philosophy to intrude upon his science. In support, we turn to the text of Pascal:

Order. I could easily have treated this discourse in this kind of order: show the vanity of all kinds of conditions, show the vanity of ordinary lives, and then the vanity of philosophers' lives, whether sceptical or Stoic, but the order would not have been kept. I know something about it and how few people understand it. No human science can keep it. St. Thomas did not keep it. Mathematics keeps it, but it goes so far as to be useless (p. 694). ${ }^{4}$

4 “Ordre. - J'aurais bien pris ce discours d'ordre comme celui-ci: 
What is important to retain from the text is the clear distinction made by Pascal between the human science and the mathematical science. Pascal prohibits the employment of the mathematical science from the service of the human science and calls this attempt 'useless'. His complaint must not be read to mean that Pascal disavowed the statistical relevance of the human science as we know it today. Instead we understand the text to mean the following: the mathematical science ignores the profusion of the human experience in order to achieve a clarification of concepts. However it is this very profusion which is the subject matter of the human science: our acts, products, and relations thereof. It is a profusion of the kinds of objects of conception. The mathematical science, on the other hand, refuses to admit this profusion of the kinds of objects; rather, it replaces profusion with multiplicity, that is, the addition of like units. It is this profusion of the human science which instinct must seek to explain in a manner which is consistent with its sharing amongst a number of subjects.

Hence it is not the case that the requisites of the mathematical method will found and elaborate a true philosophy of experience. Instead, Pascal operates a clear distinction between the scientific method and the philosophical method - to the great advantage of both. We must, therefore, disagree with the conclusion of his editor who argues for the perfection of the logical order when pressed into the service of the apology (p. 61, note 3). This tendency to read the Pensées of Pascal in the manner of a Cartesian

pour montrer la vanité de toutes sortes de conditions, montrer la vanité des vies communes, et puis la vanité des vies philosophiques pyrrhoniennes, stoïques; mais l'ordre ne serait pas gardé. Je sais un peu ce que c'est, et combien peu de gens l'entendent. Nulle science humaine ne le peut garder. Saint Thomas ne l'a pas gardé. La mathématique le garde, mais elle est inutile en sa profondeur"(p. 61). 
philosophy leads to much confusion. Moreover, the attempt to render Pascal an adherent of Descartes does not have the authority of the texts. In support, we may cite the following text: "Write against those who probe science too deeply. Descartes" (p. 553). ${ }^{5}$ The text is clear: one of the salient features of Descartes' method is that it is intended to apply to all problems - both scientific and philosophical (Discourse, pp. 12-3). Pascal does not agree with this attempt and the reasons for his disagreement may be found in the following text: "Descartes. In general terms one must say: 'That is the result of figure and motion', because it is true, but to name them and assemble the machine is quite ridiculous. It is pointless, uncertain, and arduous. Even if it were true we do not think that the whole of philosophy would be worth an hour's effort" (p. 84). ${ }^{6}$ Science writ large is non-scientific. Broad assertions of matter and form, figure and movement serve no useful purpose for they explain nothing. We suggest that in the thought of Pascal, the notion of order is important to the furtherance of both science and philosophy to the extent that it serves to limit the application of a science or of a philosophy to its proper set of objects. Once again, we turn to the text for instruction:

Cause and effect. Gradation. Ordinary people honour those who are highly born, the half-clever ones despise them, saying that birth is a matter of chance, not personal merit. Really clever men honour them, not for the same reason as ordinary people, but for deeper motives. Pious folk with

5 "Écrire contre ceux qui approfondissent trop les sciences. Descartes" (p. 76).

6 “Descartes. - Il faut dire en gros: 'Cela se fait par figure et mouvement', car cela est vrai. Mais de dire quels, et composer la machine, cela est ridicule. Car cela est inutile, et incertain et penible. Et quand cela serait vrai, nous n'estimons pas que toute la philosophie vaille une heure de peine" (p. 79). 
more zeal than knowledge despise them regardless of the reason which makes clever men honour them, because they judge men in the new light of piety, but perfect Christians honour them because they are guided by a still higher light.

So opinions swing back and forth, from pro to con, according to one's lights (p. 90). ${ }^{7}$

The gradation of which Pascal speaks is not only a gradation of social orders but more especially, a gradation of intellectual orders. It is the discernment of the objects of thought proper to each set of subjects. Thus we are able to set a second difference between the thought of Pascal and the philosophy of Descartes: for Pascal, scientific knowledge is knowledge that holds true but for a limited set of objects. Hence it happened to Pascal to engage at the same time in the study of the mechanical science and human science without being led into error upon the two sets of objects. More especially, we suggest that it is through the rational structure of noesis termed 'instinct' that our knowledge of the sensible reality finds shape and limit as common amongst a number of subjects. Commonality is not an accretion of method. Rather, its source lies within the disposition of the subject to know the sensible reality pursuant to the formation of concepts as instructed by instinct. For Descartes, on the other hand, there is operated no clear distinction of method and object of noesis. The case of the innate idea of matter is revealing. The idea

7 “Raison des effets. - Gradation. Le peuple honore les personnes de grande naissance. Les demi-habiles les meprisent, disant que la naissance n'est pas un avantage de la personne, mais du hasard. Les habiles les honorent, non par la pensée du peuple, mais par la pensée de derriére. Les dévots qui ont plus de zèle que de science les méprisent, malgré cette considération qui les fait honorer par les habiles, parce qu'ils en jugent par une nouvelle lumière que la pieté leur donne. Mais les chrétiens parfaits les honorent par une autre lumière supérieure. Ainsi se vont les opinions succédant du pour au contre, selon qu'on a de lumière"(p. 337). 
serves as a rule for the determination of the evidence of complex ideas. As such, it specifies the veritable object of conception. In the philosophy of Descartes, the universal method implies the universal object of noesis.

Similarily, we must not proceed to a confusion of the sciences themselves. The necessity and truth of particular assertions made within the context of a natural science need not serve to guarantee the necessity and truth of all natural sciences. Much less of all of reality. In the Pensées of Pascal, this appeal to the natural sciences is elicited in terms of the two notions of the infinitely large and the infinitely small. We cite the following famous text entitled 'Disproportion of man':

For, after all, what is man in nature? A nothing compared to the infinite, a whole compared to the nothing, a middle point between all and nothing, infinitely remote from an understanding of the extremes; and the end of things and their principles are unattainably hidden from him in impenetrable secrecy.

Equally incapable of seeing the nothingness from which he emerges and the infinity in which he is engulfed...

Because they failed to contemplate these infinites, men have rashly undertaken to probe into nature as if there were some proportion between themselves and her.

Strangely enough they wanted to know the principles of things and go on from there to know everything, inspired by a presumption as infinite as their object (p. 199). ${ }^{8}$

8 “Car enfin qu'est-ce que l'homme dans la nature? Un néant à l'égard de l'infini, un tout à l'égard du néant, un milieu entre rien et tout. Infiniment eloigné de comprendre les extrêmes, la fin des choses et leur principe sont pour lui invinciblement cachés dans un secret impénétrable, également incapable de voir le néant d'où il est tiré, et l'infini où il englouti..."

"Manque d'avoir contemplé ces infinis, les hommes ne sont portés témérairement à la recherche de la nature, comme s'ils avaient quelque proportion avec elle. C'est une chose étrange qu'ils ont voulu comprendre les principes des choses, et de là arriver jusqu'à connaître tout, par 
Science is not one but many; and Pascal rejects the attempt to know all things within one science alone. Instead, true science must respect certain limits in order to remain scientific. The notion of instinct is one such limit upon our knowledge of the sensible reality. We suggest that the notion of instinct in the thought of Pascal enables at once the adherence to a scientific order of knowledge and the shared nature of this knowledge amongst a multiplicity of subjects. Instinct does not constitute the truth of things; rather its role lies in the determination of the formative conditions necessary for a true knowledge of things. Thus we discover that Pascal does not allow the postulation of sensible qualities to influence his philosophical method. Rather than commence knowledge of a common world with the bits and pieces of perception, Pascal will attempt such knowledge based on the requisites of a conceptual cognition. It is upon the basis of the notion of instinct understood as a disposition of the human understanding that we may achieve the true knowledge of a common world.

Simply stated, we understand the notion of instinct to affirm the following: instinct is a structure of understanding common to a species. As such, it is possible to articulate the true knowledge of a common world based upon the requisites of a common structure of understanding. To begin, we cite the following text of Pascal: "Heart, Instinct, Principles" (p. 155). ${ }^{9}$ Instinct is affirmed a principle of the human understanding. It is not the case that instinct is an irrational response on the part of the subject to the object; rather, instinct is at once a principle of the human understanding proper and the repository of the first truths

une présomption aussi infinie que leur objet. Car il est sans doute qu'on ne peut dormer ce dessein sans une presomption ou sans une capacité infinie, comme la nature" (p. 72).

9 "Cœur, instinct, principes" (p. 281). 
concerning the physical nature. Instinct is a cognitional condition which enables the interpretation of experience in consonance with the physical sciences. And this affirmation receives clarification in the immediately following text:

We know the truth not only through our reason but also through our heart. It is through the latter that we know first principles, and reason, which has nothing to do with it, tries in vain to refute them. The sceptics have no other object than that, and they work at it to no purpose. We know that we are not dreaming, but, however unable we may be to prove it rationally, our inability proves nothing but the weakness of our reason, and not the uncertainty of all our knowledge, as they maintain. For knowledge of first principles, like space, time, motion, number, is as solid as any derived through reason, and it is on such knowledge, coming from the heart and instinct, that reason has to depend and base all its argument...

Our inability must therefore serve to humble reason, which would like to be the judge of everything, but not to confute our certainty. As if reason were the only way we could learn! Would to God, on the contrary, that we never needed it and knew everything by instinct and feeling! But nature has refused us this blessing, and has instead given us only very little knowledge of this kind; all other knowledge can be acquired only by reasoning (p. 110). ${ }^{10}$

10 "Nous connaissons la vérité, non seulement par la raison, mais encore par le cœur, c'est de cette dernière sorte que nous connaissons les premiers principes, et c'est en vain que le raisonnement qui n'y a point de part, essaye de les combattre. Les pyrrhoniens, qui n'ont que cela pour objet, y travaillent inutilement. Nous savons que nous ne rêvons point; quelque impuissance où nous soyons de le prouver par raison, cette impuissance ne conclut autre chose que la faiblesse de notre raison, mais non pas l'incertitude de toutes nos connaissances, comme ils le pretendent. Car la connaissance des premiers principes, comme qu'il y a espace, temps, mouvement, nombres, [est] aussi ferme qu'aucune de celles que nos raisonnements nous donnent. Et c'est sur ces connaissances du cœur et de l'instinct qu'il faut que la raison s'appuie, et qu'elle y fonde tout son discours... Cette impuis- 
From this text we may observe the following: first, the clear reaffirmation of the heart and instinct as principles of understanding. It is through the operation of the heart and the operation of instinct that we may know the first truths. And this is as true of the mathematical sciences (number) as of the physical sciences (space, time, movement). As such, instinct is ideally suited to explain our understanding of a common world insofar as it defines the a priori conditions necessary for the elaboration of the physical sciences. Second, these first truths elicited by the operations of heart and instinct are certain (solid). This affirmation is of immense importance for the proper understanding of the notion of instinct for it aids in the clarification of the nature of certitude in the thought of Pascal. Third, we observe the method of Pascal: the first truths of instinct are not subject to rational proof. Instead, their nature is opposite; they serve to instruct the employment of reason. Fourth, the position of Pascal on the nature of instinct as intelligible element is similar to the position of Descartes on the innate ideas of matter and God: they each partake of a self-evidence which resists all doubt. However, we discern an important difference between their several notions: for Descartes, the innate ideas are elemental concepts to which all subsequent concepts must be reduced. For Pascal, on the other hand, instinct is a necessary condition for the advancement of true ideas. As such, it is a rational nature which preceeds the first truths of the particular sciences themselves in order to explain their provision. But in no

sance ne doit donc servir qu'à humilier la raison, qui voudrait juger de tout, mais non pas a combattre notre certitude, comme s'il n'y avait que la raison capable de nous instruire. Plût a Dieu que nous n'en eussions au contraire jamais besoin, et que nous connussions toutes choses par instinct et par sentiment! Mais la nature nous a refusé ce bien; elle ne nous a au contraire donné que très peu de connaissances de cette sorte; toutes les autres ne peuvent etre acquises que par raisonnement" (p. 282). 
wise is instinct an element of these first truths. It is this difference of principle and element which constitutes one of the chief distinctions between the Cartesian philosophy and the thought of Pascal. Thus we may set a third difference between the thought of Pascal and the philosophy of Descartes: for Pascal, the notion of instinct is a principle and not an element of noesis; that is to say, all our ideas which bear upon the physical nature may be understood pursuant to their origin in instinct. But the converse cannot equally be claimed; all of our ideas about the sensible reality are not instinctive. For Descartes, on the other hand, the notion of principle and the notion of element are not so differentiated. All sensible ideas must retrace their intelligibility to the innate idea of matter. Alternately, the innate idea of matter is a constitutive element subsistent with each of their veracity.

To summarize, we have situated the thought of Pascal with respect to contemporary philosophers of both our and his day. We have introduced the notion of instinct as a principle of actualization of the concept in its application to things in order to address the problematic of knowledge of a common world. As well, we have set the difference between the Cartesian innate idea of matter and the Pascalian notion of instinct as cognitive condition. We have done so in three ways: first, the difference between formation and validation; second, the difference between method and object of noesis; and third, the difference between principle and element. Let us, then, proceed to an analysis of the nature of instinct, the nature of certitude, and the relation between instinct and certitude in the thought of Pascal.

\section{Instinct and Certitude}

The first truths present to the human understanding through instinct are certain. We have this from the hand 
of Pascal himself (p. 110). And this consequence obtains notwithstanding their entire lack of proof. For this to be the case, Pascal must admit a multiplicity of kinds of certainty. And, indeed, we discern two kinds of certitude in the thought of Pascal: certitude of first truths and certitude of proof. To illustrate, we make reference to a short work of Pascal entitled 'Of the Geometrical Spirit': "When geometry encounters first principles she comes to a stand, and demands that they be accepted and agreed with, for she has nothing more clear than they, by which to prove them. Thus everything that geometry proposes is perfectly demonstrated, either by proofs or by the light of nature (p. 305). ${ }^{11}$ It is timely to call attention to the employment of the term 'clear'. As both a mathematician and a natural scientist, Pascal is well aware of the importance of clarity. Indeed, it is upon the basis of clarity that the first principles of the science of geometry are deemed true. Further, Pascal's work is contemporary with the work of Descartes. The role of clarity in the philosophy of Descartes is well attested to in the literature; it is upon the basis of clear and distinct ideas that Descartes proceeds to the elaboration of a first philosophy (Meditations, p. 59). Hence the disagreement between Pascal and Descartes is not one of criteria; rather, it is one of origin. Pascal continues:

It may be thought strange that mathematics should not be able to define those things with which she is mainly concerned. She can offer no definition of movement, numbers, space;... But nobody will be surprised if we remark that since this wonderful science is concerned only with the most

11 “De l'esprit géométrique": "Car, quand elle est arrivée aux premières vérités connues, elle s'arrête là et demande qu'on les accorde, n'ayant rien de plus clair pour les prouver: de sorte que tout ce que la géométrie propose est parfaitement démontré, ou par la lumière naturelle, ou par les preuves" (p. 172). References to short works of Pascal are cited by name and page number of the Brunschvicg edition. 
simple ideas, the very quality which makes them suitable for study also makes them incapable of being defined; so that the absence of a definition is a perfection rather than a defect. This absence does not arise from obscurity, but on the contrary from their extreme obviousness, which is of such a nature that while geometry cannot carry conviction by demonstration, she has all the certitude that demonstration could produce (pp. 305-306). ${ }^{12}$

There are two kinds of certitude: the conviction of demonstration and the certitude of first truth. For the present study, our interest is limited to the second kind. It is admitted that the first truths of the physical sciences are not susceptible of proof, but this exclusion does not constitute a sufficient reason to discredit their certitude. This exclusion pertains equally to the geometrical sciences as the physical sciences grounded upon instinct. Further, the text reveals that Pascal understands this lack of proof in a positive way: the elements of noesis which are at once clear and impervious to proof must be true. These are the criteria for the the first truths of science, such truths as are given to the subject through the operation of the heart and instinct. Thus we see more clearly the procedure of Pascal: the first truths of the physical sciences are deemed true because they are given to us by instinct. They are the first product in the formation of concepts by instinct. As such, it is in their nature to be entirely simple. This is

12 “On trouvera peut-être étrange que la géométrie ne puisse définir aucune des choses qu'elle a pour principaux objets: car elle ne peut definir ni le mouvement, ni les nombres, ni l'espace;... Mais on n'en sera pas surpris, si l'on remarque que cette admirable science ne s'attachant qu'aux choses les plus simples, cette même qualité qui les rend dignes d'être ses objets les rend incapables d'être définies; de sorte que le manque de definition est plutôt une perfection qu'un défaut, parce qu'il ne vient pas de leur obscurité, mais au contraire de leur extrême evidence, qui est telle qu'encore qu'elle n'ait pas la conviction des demonstrations, elle en a toute la certitude" (p. 173). 
the lesson to be learned from instinct: understood as an inborn disposition of the subject to form concepts concerning the physical reality, these first truths must be simple, else they would not be first. The problem of the origin of intelligibility — of procession — which the pragmatist ignored now finds a solution. The first truths of the sensible reality find their origin in instinct; it is the inborn disposition of the subject which provides for their truth based on their extreme simplicity. The noetic evidence of their simplicity is clarity. Thus in the thought of Pascal, the notion of simplicity replaces the Cartesian notions of clarity and distinction as the ground for the discernment of truth and falsehood. More precisely, simplicity underlies the notions of clarity and distinction in order to explain their noetic as distinct from psychological truth.

Accordingly, we can now make room for the pragmatic notion of harmony. The cognitive condition termed 'instinct' is the source of all first truths of the physical sciences. These first truths - space, time, and motionevidence a harmony based on their extreme evidence and simplicity. Hence in the thought of Pascal, the accord of science follows upon the immanent nature of the first truths; that is to say, their priority. They bear at once the simplicity of their origin and the clarity of their understanding. Thus the harmony of science is a harmony based not on a felicitous result but rather upon the requisites of order and priority of conception.

Further, we observe a difference of terminology: the truth of demonstration is termed 'conviction'; the truth of first principles, on the other hand, is termed 'certainty'. The noetic perception to be achieved through the application of proof is of a separate kind from the noetic perception to be achieved through the grasp of first truths. The text is clear: that which Pascal seeks to distinguish is the indubitability of first principles from the exact appli- 
cation of method. The former is deemed independent and superior to the latter. To this extent, the position of Pascal agrees with the position of Descartes: the human subject is full of beliefs and to know truly is to be able to discern those beliefs which have the guarantee that it is right to believe in them. For both philosophers, the acknowledged guarantee is one of certitude; and in both cases, certitude is understood in terms of the criterion of clarity. Where they seem to differ is in the determination of clarity amongst the first truths. For Pascal, these truths are clear because they are the first products of their formative principle; that is, of instinct. For Descartes, on the other hand, the ideas of the physical sciences are clear consequent to their validation by the innate idea of matter.

However, to arrive at a better understanding of instinct we must examine more fully the notion of certitude in the thought of Pascal. Pascal oftentimes writes of certainty and the effect it has upon the human subject as an effect of feeling. The use of this terminology has led some readers of Pascal to support a number of interpretations on the nature of his thought. One such attempt at interpretation may be found in the thesis of Psychologism:

A look at Pascal on proof suggests somewhat paradoxical but very powerful answers to these questions. At bottom, says Pascal, reason is a kind of rhetoric, a power that persuades us, at times irresistibly, as in the case of first principles. When all is said and done, he argues, we find rational argument to be probative not merely because it observes certain formal rules, but because the observance of those rules persuades us of the truth of what follows them. We cannot but take as proof, he concludes, those things that do in fact convince us (Natoli, p. 20).

We cannot agree with the thesis of Psychologism in the thought of Pascal. Instead, we proceed to the following qualifications: first, there has been established a firm 
distinction operated by Pascal between the conviction of demonstration and the certitude of first truths. It is not the case that Pascal grounds the certitude of first truths upon the effect of feeling; rather, it is the case that the certitude of first truths resides in their entire clarity - a clarity which is the noetic perception of their conceptual simplicity. Second, the text of Pascal (p. 110) suggests a difference of meaning and status between instinct and feeling. We understand the employment of the term 'and' to imply a succession of meaning and kind. If instinct were synonymous with feeling, what need would there be for Pascal to repeat himself? And Pascal is not a thinker much given to redundancy. Hence the very hand of Pascal suggests that the certainty of instinct is of a kind other than the certainty of demonstration - of the feeling of conviction. Third, we suggest that the notion of instinct evidences the nature of the conceptual process in the manner of a cognitive condition. It is a form of understanding which explains the origin of intelligibility of the physical sciences. As such, the notion of instinct is the a priori condition of thought necessary for the determination of the first truths of the sensible reality; it is a conceptual structure which specifies the rational nature necessary for a common knowledge of the world. We have already discerned the noetic nature of instinct to be simplicity. As such, it may be understood to stand prior to any claims of demonstration - such claims which may or may not include the experience of conviction. Thus we cannot agree with the conclusion of Natoli: "For Pascal, all proof relying on merely human resources should be seen as being fundamentally audience-relative" (p. 30). The cognitive condition termed 'instinct' specifies the first truths of both the geometrical and the physical sciences in the primary act of conception of the living being. This of itself does not in any way imply that its truth is "audiencerelative". Rather, that which it implies is the exactitude of 
the conceptual process: it is the assurance that upon the basis of instinct as a conceptual condition of thought, we can proceed to a formulation of the physical sciences which instantiate the actuality of the truth of instinct; that is, its simplicity.

\section{Instinct and Method}

Pascal accepts the criterion of certitude as the necessary sign of truth of the first truths of the sensible reality. But there remains a prior state in the cognitive life of the subject; it is the stage of instinct. We suggest that instinct is a form of understanding which grounds our experience of indubitability within the rational life of the subject. It is a cognitive condition of the subject which enables the subject to conceive with certitude the first truths of the natural sciences. We have explained this notion of certitude to subsist within the simple nature of instinct. Following, we envisage two exegetical elements which explain the cognitive condition termed 'instinct': that of nature and that of method. The exigency of nature is to be understood pursuant to the notion of intuition; the exigency of method is alternately to be understood pursuant to the nature of synthesis.

We first turn to the exigency of method. As we have seen, the texts of the Pensées suggest a difference of method in the thought of Pascal and Descartes (p. 84). In this wise, Pascal is oppositely situated with respect to Descartes on the nature and purpose of Logic. Unlike his famous contemporary, Pascal does not seek to deduce the first principles of philosophy from the reduction of a complex into its elemental parts. The principles of human understanding are not understood by Pascal to be the effect of analysis; rather, they are the effect of nature. The Pascalian method is a method of demonstration. For Descartes, on the other hand, the method is one of analysis; it is a method of dis- 
covery. In his history of early Logic, A.C. Lloyd explains clearly this difference, in particular, with respect to the Platonic and Aristotelian traditions:

First, what does 'analysis' mean in our context? The standard explanation of going $u p$, i.e. back, from an end to a beginning, is Peripatetic as well as Platonist... For (I)(b) Imperial logicians were ready to assume that when " $p$ and $q$, therefore $r$ ' was asserted ' $r$, if $p$ and $q$ ' could be asserted; this is why analysis was called 'the converse of demonstration'. But, more important, it was seen epistemologically: someone who knew what premisses yielded a given conclusion was in possession of a proof form, which was simply the synthesis that was the converse of the analysis (p. 10).

The method of demonstration recommended by Pascal includes the assumption of the premiss. As such, the premiss - in this case the first truths of instinct - remains indubitable. What, then, is the epistemological importance of the preference for the method of demonstration as opposed to the preference for the method of discovery in the thought of Pascal? We suggest that the election of this method enables Pascal to maintain the nature of instinct as ground of both necessary and synthetic truths. In particular, it is a kind of knowledge which forms the conception of universals - common concepts which we all share and which elaborate our knowledge of a common world. Some of these concepts Pascal himself has named: space, time, and motion.

The form of understanding called 'instinct' is the conceptual condition which specifies the first truths of the physical sciences. It is the intelligible element subsistent within the subject which makes the first truths insofar as it sets the limits within which thought may operate. These limits attain the specificity of an idea upon application to things of the world; that is, the ideas of space, time, and 
motion. A comparison with the Creative Reason of Aristotle is instructive. We cite the following passage from the introduction to the De anima by Wallace:

Long before the individual has come to know the ultimate ideas he has unconsciously to himself applied them in building up his own experience: it may be that he never consciously recognises the existence of such ideas at all. But this thinking of the world is never really in abeyance: and if we leave the individual and consider the subject in the absolute we shall see that this potential thought is not really prior even in time to creative reason. This reason in fact is always implicitly present in the world: it does not think at one time, and rest from thinking at another; that is, if we may again supplement Aristotle, our categories of thought are ever active in the world, because, however unconscious we may be of them, it requires only an effort of introspection to discover them as necessary ingredients of our experience (cv).

Thus in the history of philosophy, Pascal is far from being alone in the ascription of a not always entirely conscious form of understanding in the living being. Of itself, instinct is neither synthetic nor analytic. Rather, we understand instinct in the manner of a conceptual condition: it is the a priori ground for the understanding of first truths concerning the sensible reality. Its nature is to be a generic principle which produces the first truths necessary for science. It is these truths which evidence and constitute the synthetic actuality of noesis. Similarily, it is these truths which evidence and constitute the indubitable actuality of noesis.

Instinct is the intelligible element located within the subject which conditions the first truths to be at once necessary and synthetic. What is unique to Pascal is the conjunction of this epistemological choice of synthesis with the notion of instinct. Instinct is the a priori condition of 
thought which enables the elaboration of a common world based upon the synthetic function of demonstration. This result of synthesis agrees with the affirmation of instinct as a formative principle of conception. We are now able to better understand this affirmation: it is a condition of thought which sets forth the first truths of the sensible reality from which synthetic propositions may be drawn. Pascal himself provides an example: "For how many people think they have defined 'time' when they call it 'the measure of movement', and yet leave it with its ordinary significance? Although in this form it is a proposition, and not a definition" ("De l'esprit géométrique" 304). ${ }^{13}$ The formation of a judgement consequent to the employment of first truths toward a number of objects - ideal or realis the act of synthesis. In the case herein cited, we have the conjunction of time - a first truth given to the subject by instinct - with motion - another first truth also given by instinct. In contrast, the Cartesian innate idea of matter does not lead to the formation of synthetic propositions concerning the sensible reality. Its role is limited to the validation of complex ideas into their elemental parts. Hence we maintain our position: the intelligible element within the human subject termed 'instinct' is the ground for the elaboration of synthetic judgements. These judgements specify our understanding of a common world to the extent that they elaborate upon the first truths of the physical sciences, truths such as space, time, and motion.

An objection arises: do we not misinterpret the spirit and letter of the text? In the thought of Pascal, notions such as space, time, and motion are primitive terms. His position is that of a nominalist ("Of the Geometrical

13 "Car combien y-a-t-il de personnes qui croient avoir défini le temps quand ils ont dit que c'est la mesure du movement, en lui laissant son sens ordinaire? Et néanmoins ils ont fait une proposition, et non pas une définition" (p. 171). 
Spirit," p. 299). ${ }^{14}$ We reply in the following manner: we do not dispute the nominalism of Pascal but instead seek to differentiate between a methodological function which explains the attribution of names to ideas, from the conceptual function of cognitive condition - the generation of first truths necessary for the elaboration of synthetic propositions. That is to say, we must separate logic from physics. The word 'physics' is being used to describe the speculative understanding of the nature of things pursuant to their material characteristics as discovered through experience. Hence we may understand more clearly the disagreement of Pascal with linguistic philosophy. For Pascal, we must not seek to determine the nature of things consequent to our employment of language. Rather, the opposite is true: we employ language in order to elucidate our understanding of nature. Nominal definitions are a mere facility which frees the subject from long repetitions of words; they constitute nothing more than an aide mémoire for they enable the subject to ascertain the correctness of a demonstration in consonance with the proper employment of the terms.

The following text of the Pensées supports our interpretation of Pascal: "Instinct, reason. We have an incapacity for proving anything which no amount of dogmatism can overcome. We have an idea of truth which no amount of scepticism can overcome". 15

If we read the text correctly, it would seem to be the case that Pascal argues the following: the true idea of which it is question is an idea given to us by instinct. And as instinct, together with heart, form the seat of all first principles, its truth is necessarily true. Indeed, the french text is clear:

14 “On ne reconnaît en géométrie que les seules définitions que les logiciens appellent définitions de nom..." (pp. 165-166).

15 Instinct./Raison. "-Nous avons une impuissance de prouver, invincible à tout le dogmatisme. Nous avons une idée de la vérité, invincible à tout le pyrrhonisme" (p. 395). 
Pascal employs the term 'invincible' which we understand to mean irrefutable. The text constitutes a second indication of the impossibility of proof with regards to matters of instinct. But such a restriction is not construed as detrimental to the validity of instinct insofar as the first principles known by the rational nature are deemed independent of discursive proof. Such principles are given in the most absolute sense of the term. Again, we may cite the following text:

But it does not then follow from this that all systems of order have to be abandoned.

For there is one such system which is less esteemed, not because it is less certain but because it is less convincing. This is the method of geometry. It neither defines nor proves all the things that are, and for this reason it fails to convince, and yields pride of place to other sciences; but it assumes nothing but what is clear and constant and according to the light of nature, and for this reason it is perfectly reliable ("Of the Geometrical Spirit", p. 301). ${ }^{16}$

His is not a verification theory of meaning. The first truths of the geometrical and of the physical sciences are not subject to empirical or rational verification. The guarantee of their truth is immanent: it resides within their clarity and simplicity. The attempt at rational validation which the theory of verification implies does not and, indeed, cannot apply to the first truths of instinct. Rather, it is these truths given to us through instinct which serve to

16 “Mais il ne s'ensuit pas de la qu' on doive abandonner toute sorte d'ordre. Car il y en a un, et c'est celui de la géométrie, qui est à la vérité inférieur en ce qu'il est moins convaincant, mais non pas en ce qu'il est moins certain. Il ne définit pas tout et ne prouve pas tout, et c'est en cela qu'il lui cède; mais il ne suppose que de choses claires et constantes par la lumière naturelle, et c'est pourquoi il est parfaitement véritable, la nature le soutenant au défaut de discours" ("De l'esprit géométrique", p. 168). 
control and direct the application of method - of verification. Thus we are able to better situate the consistency of the pragmatist with respect to the thought of Pascal. Pascal chooses not to pursue the solution of the pragmatist because the pragmatist does not place consistency at the foundation of our knowledge of things. Consistency, for a pragmatist, is a result. And a felicitous result at that. For Pascal, on the other hand, science is not a felicitous result. Rather, it is necessary. And this necessity is rooted in the supposition of a consistency which evidences the rational principles themselves. Again, the comments of Lloyd are judicious. "We saw earlier that logic is analysis because analysis is the discovery of proof, but that technically it was the problem which was supposed to be analysed in order to discover premisses" (p. 18). Even the logic of discovery does not serve to verify the first truths of science; it merely discovers them.

\section{Instinct and Nature}

We may now turn to the exigency of nature. The text affirms a kind of knowledge which is intuitive in nature (p. 110). We sense the first principles upon which propositions subsequently conclude. This consideration enables Pascal to introduce a new element of understanding: instinct is at once the necessary ground for the elaboration of the physical sciences and the explanation of their intuitive criteria. The physical sciences are not intuitive truths; we know the physical world scientifically through discourse but their elaboration as discourse is consequent to the formation of first truths; and these first truths are themselves intuitive. Thus we may conclude the following: instinct is a structure of conceptual cognition which enables a true knowledge of the physical world based upon the clear and simple understanding of a rational object given intuitively. 
Intuition is thus understood to mean a nonpropositional knowledge of the concept — knowledge which is a necessary condition for the truth of all subsequent propositions about the sensible reality for it establishes the grounds for the indubitability of conception. We have already met one such ground for indubitability: the notion of simplicity. It was therein explained the priority of simplicity upon clarity. It is our present task to explain the relevance of simplicity to the intuitive criteria of thought. We shall do so in two ways: the notion of prescription and the notion of recollection.

First, let us read the scientific Pascal to better situate the importance of a discussion of instinct:

Is it not undignified to place the reasoning powers of men on a level with the instincts of animals? Since we eliminate the principal difference between them, which is that the results of reasoning processes increase without cessation whereas instinct is stable, not subject to development. The cells of the honeycomb were as precisely measured a thousand years ago as they are today, and every bee constructed its first hexagon as accurately as it does its latest ("Fragment of a Treatise on Vacuum", pp. 292-293). ${ }^{17}$

This text enables us to further clarify the nature of instinct: instinct concerns the shared experience of a multiplicity of beings. It is an operation of understanding which equally extends to the rational and to the sensible orders of living beings. As such, it is ideally suited to the elaboration

17 “N'est-ce pas là traiter indignement la raison de l'homme, et la mettre en parallèle avec l'instinct des animaux, puisqu'on en ôte la principale différence, qui consiste en ce que les effets du raisonnement augmentent sans cesse, au lieu que l'instinct demeure toujours dans un état égal? Les ruches des abeilles étaient aussi bien mesurées il y a mille ans qu'aujourd'hui, et chacune d'elles forme cet hexagone aussi exactement la première fois que la dernière" ("Fragment d'un Traité du Vide", p. 79). 
of knowledge of a common world for it effects a universality of experience shared throughout the conscious living world. The collaborative aspect of the present example of Pascal is especially significant for it involves the construction of a common place - a common world (cells). If in the text of the Pensées (p. 110), Pascal addresses his remarks to the individual's grasp of first principles consequent to the operation of heart and instinct, in the current text Pascal clearly admits of a social agency of instinct.

As well, the notion of instinct is understood to lie closely with the physical nature. Knowledge of the sensible reality must first be situated within the context of instinct before we may accede to a knowledge elaborated by reason. Hence the text may be read in a positive light. While a hasty reading of the fragment may lead one to suppose that Pascal concludes a solely negative effect of instinct in comparison with reason, it can equally be argued that Pascal is equally admitting a necessity to instinct, that is, the necessity of a priority of conception. We must pass through the truths of instinct in order to attain the truths of reason.

Instinct situates the first truths of the sensible reality in the manner of a conceptual condition of thought. As such, its necessity cannot be simply logical in terms of a logic of discursive reasoning, that is, a logic of attribution and predication. Instead, if there be a logic of instinct, it must be reinterpreted in accordance with the notion of intuition. Wherein, therefore, lies the noetic truth of intuition? We suggest that its truth lies in simplicity, such simplicity as is manifested within the generative act of thought which produces the first truths of the physical sciences. We use the example offered to us by Pascal himself, that of the bee cell. A colony of bees constructs the bee hive not as a logical consequence of instinct but rather as the real outcome of their conceptual nature. There is no logical necessity which requires that the bees live in cells. Where there is necessity, 
it must lie in the broader necessity of a conceptual nature, that is, the completion of a sequence of acts which is generated within a structure of conception given intuitively; that is, given simply. What the bee does immediately, that is, through pure instinct, we do consciously through reason. We deliberate upon the nature of our shared, lived environment whereas the bee does not. Rather, the bee lives in a world of simple generation unrestricted by the further act of reflection.

As well, we must not ignore the precision of Pascal and his use of words. When Pascal writes of hexagons, he is doing so in the capacity of a natural scientist, mathematician, and apologist. Hence reference to the shape of the bee cell underscores the noetic nature of their activity. The action of the bee is not unintelligent; it is merely non-rational in the particular sense of non-discursive. The text continues:

Nature instructs them in proportion as necessity impels them; but this fragile science is lost with the necessities which called it into being. As they received it without forethought, they take no pleasure in preserving it; and everytime the instruction is given them it is new to them. For nature has no other object than the maintenance of the animal creation in a state of limited perfection, so that she instills into them this necessary knowledge, in which she allows no variation, lest the stock should deteriorate; and to which she allows no addition, lest the animals advance in understanding beyond those limits which Nature has ordained for them ("Fragment", p. 293). ${ }^{18}$

18 "La nature les instruit à mesure que la nécessité les presse; mais cette science fragile se perd avec les besoins qu'ils en ont: comme ils la reçoivent sans étude, ils n'ont pas le bonheur de la conserver; et toutes les fois qu'elle leur est donnée, elle leur est nouvelle puisque, la nature n'ayant pour objet que de maintenir les animaux dans un ordre de perfection bornée, elle leur inspire cette science nécessaire, toujours égale, de peur qu'ils ne tombent dans le dépérissement, et ne permet 
The text gives further explanation of the intuitive nature of instinct. We suggest that one of the salient characteristics of instinct as an inborn disposition of thought is the prescription of the general conditions within which living beings act; that they constitute a common world. Indeed, it is the element of prescription which affords instinct with the truth functionality consonant with its nature. We return to our example of the bee. It can be argued that the prescriptive effect of instinct upon the bee is the construction of the cell in consonance with the shape of the hexagon. Within the intelligible element of the bee, the experience of space, time, and motion is realized in the specificity of a figure. Thus instinct is the noetic ground which serves to explain the origin of the shared conceptual relations between the subject and the world as such relations are understood to evidence prescriptive rules of actuality. Instinct is the a priori condition necessary for the true grasp of things. We have understood the conceptual nature of instinct as one of simplicity; we now can further understand the noetic force of this simplicity through the notion of prescription. Unlike the pragmatist whose noetic function is dependent upon agreement, the Pascalian subject engages in a series of actions which necessarily evidence their intuitive natures as prescriptively given to them. In the case of the bee, we can say that the bee "demonstrates" its knowledge of the sensible reality insofar as it actualizes the intelligible element in the appropriate form of the hexagon. This language of prescription is not foreign to science. We are all familiar with the canons of science; that is, the laws of physical nature. The concept of science as a body of physical law given prescriptively can be traced to the beginning of our era in the attempt to categorise the

pas qu'ils y ajoutent, de peur qu'ils ne passent les limites qu'elle leur a prescrites" ("Fragment d'un Traité du Vide", p. 79). 
general statements made about the physical reality (Lloyd, p. 147). In the thought of Pascal, these laws are understood to include all living beings inasmuch as they are generated through the power of instinct. As such, the prescriptive nature of intuition is the articulation in act of the most simple forms of noesis - notions of space, time, and motionwhich serve to found our knowledge of things. Thus to the question, 'how does the bee know the sensible reality?' we may reply, "through the act of constructing an hexagon, a shape prescribed by intuition'.

We are now able to situate the notion of function in the thought of Pascal. The first truths of instinct - space, time, and motion - are the noetic explanation of the primary causal relations of the physical sciences. This role in science is important to the extent that they serve to reveal the prescriptive nature of the causal relations which exist between things and living beings in the sensible nature. Hence we witness the employment of the notion of function which is very different from the notion of function of the pragmatist. For the pragmatist, function involves the ascription of certain actions to certain ideas in order to attain agreement. For Pascal, on the other hand, function is the actualization of the intelligible element of the living being toward the formation of first truths of the sensible reality. We can say that in the thought of Pascal, the science of physics replaces the science of psychology as ground for a true knowledge of the common world.

Further, we observe the static nature of instinct: it is not subject to change. That which changes is the scientific discourse; it is the logic of demonstration which progresses. The only movement of which instinct is susceptible is that of renewal. In this wise, the cognitive condition termed 'instinct' is similar to the Platonic genus called 'rest'. Their respective conception entails the notion of maintenance as necessary to the expression and reality of truth. The role 
of instinct in the thought of Pascal is akin to the role of genus in the philosophy of Plato: the role of genus in the philosophy of Plato is the generation of rational species whereas the role of instinct in the thought of Pascal is the production of the natural sciences. And similar also is their firm separation of cognitive condition or genus from the discursive element of raison or $\delta \iota \alpha ́ \nu o \iota \alpha$.

Pascal defines instinct as a kind of knowledge ("Fragment", p. 293). Hence we are not mistaken in our approach: instinct constitutes a necessary element of knowledge insofar as it posits the first principles of the physical sciences. However, the text is cautionary.

Instinct is a science but of a fragile nature; it must be constantly recalled into action in order to be maintained. The consideration of renewal enables a further clarification of the noetic function of instinct, that of remembrance. We suggest that the primary power of instinct is recollection. To this extent, instinct is a structure of cognitional condition which is at once intuitive and recollective. The conviction which issues from discursive proof is henceforth replaced by the certitude of recollection.

Our position receives further clarification: the first principles of instinct which enable synthetic judgements of the physical reality are principles which reside in memory. Pascal explains: "Memory is necessary for all the operations of reason" (p. 651). ${ }^{19}$ It is usual to understand memory in a psychological sense but such need not be the only meaning of the term. There is also a noetic application of memory. We suggest that in the thought of Pascal true remembrance is the realization of the first principles given through instinct. Once again, we may contrast the innate idea of matter in the Cartesian philosophy and the notion of

\footnotetext{
19 "La mémoire est necessaire pour toutes les opérations de la raison" (p. 369).
} 
instinct in Pascal. For both thinkers, these elements of noesis are inborn. However, there is a fundamental difference in their respective views on memory: for Descartes, memory is a psychological mechanism which can be a source of doubt and hence error. We must traverse the long chain of reasoning as quickly as possible in order to arrive at true cognition. For Pascal, on the other hand, memory is positive in nature for it enables the actualization of the first truths of the intelligible element which result in synthetic judgements. In the case of the bee, the actualization of the shape of an hexagon in the construction of a shared living environment. To this extent, we must disagree with the views of Brunschvicg on Pascal and memory. When the editor of Pascal notes the dubious nature of memory in the thought of Descartes, he immediately assumes that Pascal must adhere to the Cartesian position following upon the text (p. 369 note 1). But our analysis shows that another understanding of the text is admissible, one which positively includes memory as the state of the intelligible element termed 'instinct' prior to the formation of the first truths of the physical sciences.

Thus instinct is a structure of understanding which may once again be favourably compared to the Platonic philosophy: the theory of remembrance. We know the nature of things consequent to the employment of memory. What distinguishes the Platonic man from the Pascalian bee is not the quality of memory; rather, it is the operation of reason. It is possible to educate the man through the use of reason; it appears to be impossible to educate the bee. And this result ensues not because the bee is stupid, but rather because its understanding of the world is limited to the employment of instinct. Its knowledge lies in pure recollection. We are now able to better situate the intuitive understanding of the physical world based on the $a$ 
priori condition of thought: this understanding is the understanding we have of first truths which reside in memory. Our solution does not imply that the common world exists solely in memory. Rather, that which it implies is the recollective nature of our grasp of a common world. We have knowledge of a common world based upon the first truths of the sensible nature and these first truths are situated in memory. The causal power of instinct lies in remembrance. Thus we attain a second clarification of the nature of function in the thought of Pascal: function is at once the prescriptive nature of instinct which directs the actualization of the first truths of the sensible reality by the living being and the recollective power of the subject to specify instinct into such actualization.

The position of Pascal makes entire sense when we look at the example of a victim of amnesia. Let us suppose that a person, after a violent accident of some kind, suffers amnesia. In a sense, the world that the victim knew no longer exists. And this consequence obtains because the memory of that world has been lost. The world, so to speak, is now foreign to the subject. The element of commonality no longer subsists although the subject of amnesia oftentimes fully retains the analytical and perceptual ability necessary to distinguish primary qualities from secondary qualities. Thus the text of Pascal introduces two new considerations for the eventual resolution of the problem of a common world: instinct is a science of rational intuitions which is shared amongst living beings and which is recollective in nature. Hence we are not mistaken in our approach: instinct is indeed the repository of the first truths necessary for a true knowledge of the sensible reality.

We return to a final text of the Pensées: "Two things teach man about his whole nature: instinct and experience" 
(p. 128). ${ }^{20} \mathrm{We}$ obtain further clarification of the notion of instinct: it is a form of understanding which enables the elaboration of a discourse of the natural sciences. As such, its effect is at once the commonality of human knowledge gathered through the agency of instinct - for we share a common nature of the human species - and the scientific quality of this knowledge - the reference to instruction. What is important to retain from the text is the notion of instruction. We witness continued affirmation of instinct as a kind of science: it is a form of understanding. And this instruction is made possible consequent to the nature of instinct as both prescribed and indubitable. Instinct, therefore, is not the chance accumulation of a series of events, actions, and effects. Its nature is to ordain the conditions necessary for the constitution of a common world consequent to its actualization in memory.

\section{Conclusion}

With these considerations in hand, we may accede to an understanding of instinct as an operation of understanding. Instinct is a rational structure which enables knowledge of ourselves and of a common world insofar as it elucidates the simple, intuitive, recollective, indubitable, and common nature of the sensible reality. As such, it serves to ground the true knowledge of a common world: it's purpose is to operate as a rule for the elaboration of experience. Accordingly, it does not of itself explain the nature of the extra-mental world in the particular. Such is the office of reason and the method of demonstration. The notion of instinct, on the other hand, elucidates the origin of a science of a common world pursuant to an understanding of the intelligible element as disposition.

20 "Deux choses instruisent l'homme de toute sa nature: l'instinct et l'expérience" (p. 396). 
As well, we have set the two noetic considerations for the necessity of instinct: that of simplicity and that of intuition. The necessity of simplicity is evidenced in clarity; the necessity of intuition is evidenced in the recollective power of prescription. The notion of instinct lies at the very origin of science for it explains the physical as distinct from psychological nature of such necessity.

With the notion of instinct, Pascal forgoes the traditional examination of the problem of a common world in terms of primary and secondary qualities as was current in his day. His is not the election of a perceptual problem; rather, it is a conceptual problem. Following, we have observed his employment of the notions of procession, harmony, and function which were made familiar to us by the pragmatist. As well, his approach to the problem of a common world in terms of rational intuitions and recollection removes the analysis of language to a discourse which is ulterior to the discourse of first truths; instead, it is a study which falls within the purview of a logic of demonstration. We discern continued reference to an alternate solution in the thought of Pascal based upon instinct as cognitive condition.

In the Pensées of Pascal, we discover a response to the problem of a common world which does not ignore the question of origin as was the case with the pragmatist. While the pragmatist elicits the procession of mental states and attempts their synthesis in terms of a harmonious result, the question concerning the origin of this noetic procession is left unattended. In the thought of Pascal, we discern a response to this question: it is the notion of instinct as origin of the first truths of the physical sciences. We understand the nature of instinct to guarantee the indubitability of demonstration as evidenced in the proofs of the physical sciences. Similar to the pragmatic notion of procession, Pascal is able to ground the noetic nature of the physical sciences upon a concept of formation which has its 
origins in instinct, that is, in simplicity. All first principles flow from the heart and instinct - forms of understanding whose natures are certain. Thus unlike the pragmatist, his development of instinct into a series of first truths is not psychological in nature; rather, it is conceptual.

We may henceforth understand the reason why Pascal did not attempt a solution to the problem of a common world based solely upon pragmatic or linguistic considerations: to do so is to engage in a confusion of conception. The form of unity called 'instinct' together with the first truths of the physical sciences are not the result of analysis. Their purpose is to elaborate a discourse of the human nature and of the physical sciences consequent to their actuality and generation. Of themselves, they are prior to linguistic or pragmatic analysis. In a word, the solutions of the pragmatist and of the philosopher of language are solutions which follow upon instinct. They do not constitute a solution of conceptual condition which explains both the origin and truth of our judgements about the world.

\section{REFERENCES}

Aristotle, Aristotle's Psychology, introduction by Edwin Wallace (New York: Arno Press, 1976).

Ayer, A.J., The Problem of Knowledge (Harmondsworth: Penguin Books Ltd., 1956).

Descartes, René, Discourse on Method, trans. Laurence J. Lafleur (New York: The Library of Liberal Arts, 1950).

- Meditations on First Philosophy, trans. Laurence J. Lafleur, 2nd. ed. (New York: The Library of Liberal Arts, 1960).

James, William, "The Relation between Knower and Known," The Meaning of Truth (Ann Arbor: The University of Michigan Press, 1970), pp. 102-120.

- "The Tigers in India," The Meaning of Truth (Ann Arbor: The University of Michigan Press, 1970), pp. 43-50. 
Lloyd, A.C., The Anatomy of Neoplatonism (Oxford: Clarendon Press), 1990.

Natoli, Charles M., "Proof in Pascal's Pensées: Reason as Rhetoric," Meaning, Structure and History in the Pensées of Pascal, a Colloquium organized by the University Honors Program, 5-6 April, 1989, ed. David Wetsel (Seattle: Portland State University, 1990), pp. 19-32.

Pascal, Blaise, "Discours de l'esprit géométrique," Pensées et opuscules, ed. Léon Brunschvicg (Paris: Librairie Hachette, 1945), pp. 164-195.

_ _ "Fragment d'un Traité du Vide," Pensées et opuscules, ed. Léon Brunschvicg (Paris: Librairie Hachette, 1945) pp. 7484.

- "Fragment of a Treatise on Vacuum," The Essential Pascal, ed. Robert W. Gleason, trans. G.F. Pullen (New York: Mentor-Omega Books, 1966), pp. 288-296.

—_, "Of the Geometrical Spirit," The Essential Pascal, ed. Robert W. Gleason, trans. G.F. Pullen (New York: MentorOmega Books, 1966), pp. 297-327.

—_, "Pensées," Pensées et opuscules, ed. Léon Brunschvicg (Paris: Librairie Hachette, 1945), pp. 317-749.

- Pensées, trans. A.J. Krailsheimer (London: Penguin Books, 1966).

Plato, Sophist, trans. John Warrington (London: J.M. Dent \& Sons Ltd, 1961). 


\section{RESUMEN}

El artículo aborda el problema de un mundo común desde un punto de vista epistemológico. Pretende descubrir en el sujeto el elemento inteligible que fundamenta nuestro conocimiento del mundo. Encontramos este elemento en la noción pascaliana de instinto. A continuación se explica la noción de instinto de cinco maneras diferentes: primero, se establece el contexto de la discusión mediante la confrontación de las filosofías pragmática y lingüística contemporáneas con el pensamiento de Pascal. Se sostiene que Pascal no adoptó sus soluciones, ni las de las prácticas psicológica y lingüística. Asimismo, se incluye una introducción a la filosofía de Descartes y la doctrina de las ideas innatas por ser de especial importancia para el esclarecimiento de la noción de instinto. En segundo lugar, se plantea una distinción entre principio y elemento. En tercero, se explica el carácter noético del instinto mediante un análisis de la certidumbre; se afirma que la certidumbre del instinto está basada en su sencillez. En cuarto lugar, se establece la importancia metodológica del instinto con respecto a los juicios sintéticos sobre la realidad sensible. Y en quinto, se identifica la importancia de la realidad sensible y el carácter noético de su recopilación. Ésta es la noción de instinto como base de nuestro conocimiento de un mundo común.

[Traducción de Gabriela Montes de Oca V.] 